\title{
Family Decision Making in the Indian Hinterland: Lessons for the Marketers
}

\author{
Sadaf Siraj *
}

\section{Abstract}

Given that India is one of the world's largest consumer markets and is an emerging world economic champion too, this market presents a potentially vast untapped source for research and business. $69 \%$ of Indian population is residing in villages (Census, 2011), these rural markets demonstrate linguistic, regional diversities and economic disparities, and hence are considered to be more complex to deal with than the urban markets.

This paper attempts to explore the dynamics of family purchase behavior in the rural context by means of a survey of 152 families from eight villages of Aligarh district (Uttar Pradesh, India). The study empirically investigates the relative involvement of family members in the different stages of decision making. The impact of members' position in the family has been tested on in the purchase decision stages (idea initiation, information collection and final decision) for specific products and also product related sub-decisions (amount to be spent, when to purchase, what brand, type, size, color and quantity to purchase and from which dealer). Statistical tools like Kruskal-Wallis-H test have been employed to analyze the data collected.

The findings of the study point towards a gradual shift from unilateral decision making to joint decision making process marked by increased participation of females and

* Assistant Professor, Department of Management, FMIT, Jamia Hamdard, New Delhi; sirajsadaf@gmail.com 
children. Also, significant differences were observed in the involvement of family members in the purchase decision process depending upon the nature of the product, stages of the purchase decision process, and the sub-decisions related to purchase.

Keywords: Family Decision-making, Spousal role in decisionmaking, Rural consumer, Individualized joint families, Rural Buying Pattern, Unilateral decision-making, Children as decision makers

\section{Introduction}

The family is the most important consumer-buying organization in society, and family members constitute the most influential primary reference group (Kotler, 2003). Since 1970 the interest of consumer researchers increased in examining the extent and nature of husband-wife influence in purchase decisions after the pioneering work of Davis (1970, 1971, 1974, and 1976). The information about who influences the purchase decision within a family setup serves as the basic input in designing the marketing communication and subsequently in media selection. Researchers have categorized household decision making as husband dominated, wife dominated, syncretic (joint decision) and autonomic (individualized decisions) (Herbst, 1952; Davis \& Rigaux, 1974 and Lavin, 1985)

The purchase of a consumer durable product is an important occasion in Indian families (Kapoor, 2003). A large number of family and social factors influence consumer purchase decision process (Gupta \& Chundawat, 2002). They evolve from a consumer's formal and informal relationships with other people. There are distinct roles in the family decision process, which throw light on how family members interact in different consumption related roles.

Historically, Indian society has long been male dominated, with women deferring to men and serving in subordinated positions both at home and in the work place, but as literacy rate is picking up, income level rising, and their being gradual but steady transition from an agrarian to an industrial economy from traditional family to democratic family setup, the role of women is 
changing and is further expected to change greatly. Women are becoming increasingly aware of their rights and are marching shoulder to shoulder with men. Thus, their role in purchase decision making and actual buying has also undergone a drastic change. The male (breadwinner) is no longer the sole authority in purchase decision making (Dobhal, 1999).

Vincent (2006) in his study found high level of brand awareness among children, their influence in the decision making process and independent decision making in case of FMCG's. Another study by Mishra (2006) found brand preference among children in the high involvement category including cars, computers and cell phones etc. Researchers Halan (2003) and Kashyap (2005b) also indicated the influence of children in the urban settings.

Thus, we need to empirically verify their respective roles and levels of involvement during purchase decisions before conclusions are drawn and the findings are used as inputs for formulating marketing strategies for the rural consumer considering the fact that almost $68 \%$ of Indian population lives in rural areas offers a cornucopia of opportunities to companies who venture to brave it. This kind of study assumes a greater significance due to the simple fact that rural consumer is different from his urban counterpart (Aneja, 1996; Sathyavathi, 1996; Dey \& Adhikari, 1998; Kashyap, 2000; Krishnamoorthy, 2000; Krishnamacharyulu \& Ramakrishnan, 2002; Manjunatha, 2004).

\section{Review of Literature}

In the context of role of females in the urban settings, a gradual shift is discernable with more and more women taking up jobs and consequently influencing the decision process (Khan, 2000), While Pareek (1999), Krishnamurthy \& Lokhande (2000), Khairoowala \& Siddiqui (2001), Lokhande (2004), Nagaraja (2004) indicate the increasing influence of women in the buying process even in the rural context, Krishnamurthy \& Lokhande (2000) and Suri \& Singh (2003) found brand awareness among the rural children.

Children have not been observed to have a large impact on instrumental decisions such as how much to spend (Kaur, 2003; Singh and Kaur, 2004; Verma, 1982), but rather play a role while 
making expressive decisions such as color, model, brand, shape, and time of purchase (Sen Gupta and Verma, 2000; Singh, 1992; Synovate, 2004) as validated in the West as well According to Kaur\& Singh (2006) while younger children clearly affect parental behavior and purchases, adolescents have full cognitive development and possess an understanding of the economic concepts required for processing information and selection. Veni \& Vishwanath (2011) tried to find the role of children in family purchase decision in Hyderabad, in case of selected products such as Household furniture, automobiles, personal computer, Household appliances, Breakfast cereals and in vacation decisions. It was found children though not much, exhibit a considerable amount of influence in house hold purchases and with the increase in their age their influence also increases.

According to Singhla \& Kumar (2011) in personal care products where the brand is not visible at the time of consumption (Spaghetti), and where the product is transformed considerably by the time it is consumed, the female spouse partner is an autonomous buyer for the joint consumption. However, a large number of purchase decisions are likely to be joint, if their consumption is also joint. It was also observed that there are some determinants which make an impact of spousal decision making process and they are social class of the family to which the spouse belongs, role orientation, life cycle, importance of purchase, perceived risk and time pressure - all these imposing upon whether a buying decision will be joint or autonomous.

According to Ali, A. et al (2012), children especially boys, in the age group of 14-16 years, have more influence than girls in the same age group. Moreover, this influence increases when parents are professionally more involved than otherwise.

From the survey of the extant literature, it becomes clear that the researchers in India have till date focused more on the purchase behavior of individual rural consumers. Studies addressing the issue of involvement of family members during different stages of the decision-making process and the various related sub-decisions are few and far between (Sayulu \& Reddy, 2002; Shivakumar \& Arun, 2002; Lokhande, 2003; Lokhande, 2004; Nagaraja, 2004). 
Rural buyers in India provide a tremendous range of contradictions and paradoxes which baffle the marketers who had an urban mindset and, even more so, the foreign observers. Rural consumers are far less homogeneous than their urban counterparts and differ from region to region (Bargal, 2004) The buyer in rural India is strongly bogged down to local social and cultural pressures (customs, habits, religion, attitude and their interplay) with their indomitable influences on the buying pattern (Kashyap, 2000; Mathur, 2005).

A survey of a village conducted by Clarion McCann revealed that brand consciousness among the rural folk is quite significant (Mathur, 2005). According to Nandgopal \& Chinnaiyan (2003) the level of awareness among the rural consumers about the brands of soft drinks is high. Rural consumers especially those belonging to the higher income category are becoming more brand conscious, they avoid buying from Haats ${ }^{1}$ as branded and premium products are usually not available there (Khairoowala \& Siddique, 2001).

Kashyap (2005) asserts that though individuals are branching off to form nuclear families (with separate cooking arrangements) they continue to live in the traditional family compound (under one roof). According to researchers like Kashyap (2005a) in the urban family, the husband, wife and often-even children are involved in the buying process. But in a village, because of lack of mobility and very little contact with the market, it is the men who make the purchase decisions but this trend is changing slowly but steadily. Women have started participating in the buying process though not as much as their urban counterparty (Khairoowala \& Siddiqui, 2001; Krishnan, 2002; Lokhande, 2004; Nagaraja, 2004). An interesting trend that is emerging and being observed by the researchers (Nagaraja, 2004; Doctor, 2005) is that daughters-in-law can be important agents for change in the consumption patterns of rural households

${ }^{1}$ Haats are the oldest outlets to purchase household goods and for trade in the villages. They are periodic markets whose place changes every week. About 47,000 haats are held annually in India (Chatterjee, 1996). 
Women's autonomy in decision making is positively associated with their age, employment and the number of children. (Acharya et. al. 2010) Women from rural area and Terai region have less autonomy in decision making in all four types of outcome measure. Western women are more likely to make decision in own health care, while they are less likely to purchase daily household needs. Women's increased education is positively associated with autonomy in health care decision making.

\section{The Need for the Study}

Gradual changes have taken place in the rural setup due to a gradual shift from agriculture to non-agricultural activities (Bijapurkar, 2002) and emergence of 'individualised joint families' (Kashyap, 2005b), and increased literacy and media exposure. Earlier women and children as such had no role to play in the decision making process, however, now due to the aforementioned reasons their level of participation has significantly gone up (Pareek, 1999; Khairoowala, 2001; Lokhande, 2004; Nagaraja, 2004).

Another aspect that deserves attention is that the family memberinfluence is not static and is likely to shift, depending upon the specific product or service (Converse, Huegy \& Mitchell, 1958; Wolff, 1958; Beckman and Davidson, 1962, Ferber and Lee, 1974; Wilkes, 1975; Davis, 1976 and Woodside \& Motes, 1979) and the specific stage in the decision-making process (Davis \& Rigaux, 1974; Park \& Lutz, 1982 and Belch et al., 1985). Thirdly, it also depends on the specific purchase factors (Belch et al., 1985).

Interestingly, most of the studies on family purchase behavior and decision-making process are US centric (Brehl \& Callahan Research, 1967; Bernardt, 1974; Cunningham \& Green, 1974; Davis \& Rigaux, 1974; Bonfield, 1978; Burns \& Devere, 1981; Belch et al., 1985) and only a few studies have been conducted in the Indian context (Dhobal, 1999; Khan, 2001; Gupta \& Chundavat, 2002; Kapoor, 2003) and that too focusing on the urban families.

As the influence of the family members in product purchase decisions is likely to vary across cultures and regions, the findings of US centric studies as well as those related to urban context in India cannot directly be applied to family decision making in rural 
India, without verification. Thus, through this study, an attempt has been made to explore the dynamics of family purchase behaviour for selected products in the rural context.

\section{Research Objectives}

The study broadly attempts to empirically investigate the patterns of family purchase behaviour for selected products in the rural context. Keeping the same in mind, the following objectives were set:

1. To investigate the relative involvement of husband, wife, children and grandparents in the purchase of specific products (i.e. product specific influences).

2. To investigate the effect of individual's position in the family on the involvement in the purchase decision stages, i.e. the relationship between the independent variableindividual's position in the family (i.e. husband, wife, son, daughter, grandfather, grandmother) and the dependent variables- stages in the decision process (i.e. idea initiation, information collection and final decision making).

3. To investigate the effect of individual's position in the family on the involvement in the product related subdecision (i.e. amount to be spent, when to purchase, what brand, type, size, colour and quantity to purchase and from which dealer) for four products - television, radio, edible oil and tooth paste.

\section{Hypotheses}

The study is primarily based on the premise that the individual's position in the family - independent variable - and stages and subdecisions in the purchase of specific products - dependent variable - are independent of each other as far as the relative involvement of different family members is concerned. The hypotheses considered are reflective of this premise.

$H_{01}$ : There is no relationship between the individual's position in the family and involvement in the idea initiation stage during the purchase of selected products. 
$H_{02:}$ There is no relationship between the individual's position in the family and involvement in the information collection stage during the purchase of selected products

$H_{03:}$ There is no relationship between the individual's position in the family and involvement in the final decision- making stage during the purchase of selected products

$H_{04:}$ There is no relationship between the individual's position in the family and involvement in the sub-decision 'amount to be spent' for selected products

$H_{05}$ : There is no relationship between the individual's position in the family and involvement in the sub-decision 'timing of the purchase' of selected products

$H_{06:}$ There is no relationship between the individual's position in the family and involvement in the sub-decision 'brand' of selected products

$H_{07:}$ There is no relationship between the individual's' position in the family and involvement in the sub-decision 'type' of selected products

$H_{08:}$ There is no relationship between the individual's position in the family and involvement in the sub-decision 'colour' of selected products.

$H_{09}$ : There is no relationship between the individual's position in the family and involvement in the sub-decision 'dealer' of selected products

\section{Rationale for Product Selection}

The rationale behind the selection of the aforementioned products for the present study was that these products represent buying situations ranging from complex buying decisions (e.g. television) to relatively less complex ones (e.g. tooth paste) and also the number and type of role played by various family members is expected to vary in each case. Further, since the products were of use to all members of the family their participation in decision making for the same was assumed. 


\section{The Methodology}

The research instrument designed for the study consisted of structured questionnaire and the respondents were required to indicate their level of involvement with the help of three-point rating scale viz. HI (highly involved), MI (moderately involved) and NI (not involved). The simple scale format allowed the researcher to easily collect data even from children who possess varying cognitive levels.

Data was collected from a sample of rural families consisting of husband, wife, children and grandparents. These families were residing in eight different villages of four blocks that were randomly selected from Aligarh district (Uttar Pradesh, India). Of the 241 families (randomly picked up from an exhaustive list prepared by the researcher) that were initially approached, those households were identified that had purchased at least two of the durables during the last two years to minimize forgetting effect (Khan, 2000), or had not received the same as dowry ${ }^{2}$ during marriage in the household or as gifts from a relative living in a city. This resulted in a sample of 176 households; questionnaires were administered to these households. After collecting the data from 176 households, it was found that questionnaires from 152 families (499 individuals) were suitable for further analysis.

While administering the questionnaire, the members of the family were instructed not to confer or consult with one another and the researcher made it a point to be present so as to respond to doubts and queries regarding the questions in the research instrument. The researcher personally assisted the children in filling up the questionnaire after explaining to them the contents of the questionnaire and eliciting their views.

\footnotetext{
2 Dowry or Dahej (also known as trousseau) is the payment in cash or/and kind by the bride's family to the bridegroom's family along with the giving away of the bride (called Kanyadaan) in Indian marriage. In India, size of the dowry is directly proportional to the groom's social status, and is still very common in arranged marriages and in rural areas.
} 
So as to maintain data integrity, at the very outset, the database was maintained using SPSS 17. This was essential because for each family member about 75 data entries (7 for the demographic section of the questionnaire and 68 for the decision stages and the subdecisions for the eight products under study) had to be performed. The maintenance of such a huge database (consisting of about 37,425 data cells) would have been quite cumbersome if not impossible using other available software.

For the purpose of ascertaining whether there were significant differences in the responses vis-à-vis respondent's position in the family, for the various decision stages and the related sub-decisions for each product, the Kruskal-Wallis-H Test was employed. The hypotheses were tested on the basis of significance of results. In quite a number of cases, the null hypothesis was rejected.

\section{Analysis}

For a bird's eye view, the summarized tables of results [Table 1a \& $1 \mathrm{~b}$ ] in terms of statistical significance for the various stages of decision process and related sub-decisions are given at the end. Further, detailed tables representing the Involvement of Family Members in the Purchase of each selected products is provided (see Table 2a, 2b, 2c, 2d,); wherein the mean ranks represent the degree of involvement of the family members during the different decision stages as well as sub- decisions.

At the aggregate level as can be seen from the above tables, $p<0.02$ in most cases is indicative of highly significant differences between the family members position in the family and involvement during the different stages in the decision- making process as well as the sub-decisions, implying thereby that there is a relationship between the life stage of the member and his involvement in decisionmaking process.A shift from unilateral to a more participative decision- making can be traced, Contrary to the popular belief females \& children exhibited involvement in the different stages \& sub decisions. Children showed high involvement in the idea initiation stage \& sub decisions like timing of purchase, choice of brands \& model of not only FMCGs but also higher end durables, etc. Members belonging to the middle adulthood stage seem to 
show active involvement in most of the decisions and sub stages across the different product categories.

Involvement of the members is quite product specific. Children (son and daughter) dominate the scene in the purchase related decisions of toothpaste, while the pattern that emerges in case of radio is indicative of active participation of the older age group (grandparents). The product is basically of interest to them and is a frequent source of entertainment and information. The younger generation was not much interested in the product as they are more interested in TV. Females (Wife and grandmother) showed more active participation in the decisions related to the purchase of grocery items. The general trend that is quite apparent is that in issues involving allocation of family's money, it is the husband and grandfather who matter the most. Results also indicate some kind of dyadic relationship involving consultation between the younger generation and the older one regarding the brand choice.

Table 1(a): Summary of Results for Kruskal-Wallis-H Test Individual's Position in The Family and Involvement during Stages of Decision Making

\begin{tabular}{|c|c|c|c|c|}
\hline Stage & Product & $\mathrm{P}, \mathrm{df}$ & Hypothesis & $\mathrm{HI} \rightarrow \mathrm{LI}$ \\
\hline \multicolumn{5}{|c|}{ Idea Initiation } \\
\hline & Television & $\mathrm{p}<0.02, \mathrm{df}=5$ & Rejected & $\overline{S \rightarrow G F}$ \\
\hline & Radio & $\mathrm{p}<0.01, \mathrm{df}=5$ & Rejected & $\mathrm{GF} \rightarrow \mathrm{D}$ \\
\hline & Edible Oil & $\mathrm{p}<0.02, \mathrm{df}=5$ & Rejected & $\mathrm{W} \rightarrow \mathrm{S}$ \\
\hline & Tooth Paste & $\mathrm{p}<0.02, \mathrm{df}=5$ & Rejected & $\mathrm{D} \rightarrow \mathrm{GF}$ \\
\hline
\end{tabular}

\begin{tabular}{|l|l|l|l|l|}
\hline Stage & \multicolumn{1}{|c|}{ Product } & \multicolumn{1}{|l|}{$\mathrm{P}, \mathrm{df}$} & Hypothesis & $\mathrm{HI} \rightarrow \mathrm{LI}$ \\
\hline \hline \multicolumn{3}{|l|}{ Information Collection } & \multicolumn{3}{|l|}{} \\
\hline \hline & Television & $\mathrm{p}<0.02, \mathrm{df}=5$ & Rejected & $\mathrm{H} \rightarrow \mathrm{GM}$ \\
\hline \hline & Radio & $\mathrm{p}<0.01, \mathrm{df}=5$ & Rejected & $\mathrm{GF} \rightarrow \mathrm{GM}$ \\
\hline & Edible Oil & $\mathrm{p}<0.02, \mathrm{df}=5$ & Rejected & $\mathrm{GM} \rightarrow \mathrm{S}$ \\
\hline & Tooth Paste & $\mathrm{p}<0.02, \mathrm{df}=5$ & Rejected & $\mathrm{S} \rightarrow \mathrm{G}$ \\
\hline
\end{tabular}




\begin{tabular}{|l|l|l|l|l|}
\hline Stage & \multicolumn{1}{|c|}{ Product } & \multicolumn{1}{|c|}{$\mathrm{P}, \mathrm{df}$} & Hypothesis & $\mathrm{HI} \rightarrow \mathrm{LI}$ \\
\hline Final Decision Making & $\mathrm{p}<0.02, \mathrm{df}=5$ & Rejected & $\mathrm{H} \rightarrow \mathrm{GM}$ \\
\hline \hline & Television & $\mathrm{p}<0.01, \mathrm{df}=5$ & Rejected & $\mathrm{H} \rightarrow \mathrm{D}$ \\
\hline & Radio & $\mathrm{p}<0.02, \mathrm{df}=5$ & Rejected & $\mathrm{GM} \rightarrow \mathrm{S}$ \\
\hline & Edible Oil & $\mathrm{p}<0.02, \mathrm{df}=5$ & Rejected & $\mathrm{S} \rightarrow \mathrm{GF}$ \\
\hline
\end{tabular}

$H I=$ Highest Involvement; $L I=$ Lowest Involvement

H=Husband, W=Wife, S=Son, D=Daughter, GF=Grandfather, $G M=$ Grandmother

Table 1(b): Summary of Results for Kruskal-Wallis-H Test Individual's Position in The Family and Involvement during SubDecisions

\begin{tabular}{|c|c|c|c|c|}
\hline Stage & Product & $\mathrm{P}, \mathrm{df}$ & Hypothesis & $\mathrm{HI} \rightarrow \mathrm{LI}$ \\
\hline \multicolumn{5}{|c|}{ Amount Decision } \\
\hline & Television & $\mathrm{p}<0.02, \mathrm{df}=5$ & Rejected & $\mathrm{H} \rightarrow \mathrm{D}$ \\
\hline & Radio & $\mathrm{p}<0.01, \mathrm{df}=5$ & Rejected & $\mathrm{GF} \rightarrow \mathrm{D}$ \\
\hline & Edible Oil & $\mathrm{p}<0.02, \mathrm{df}=5$ & Rejected & $\mathrm{GM} \rightarrow \mathrm{S}$ \\
\hline & Tooth Paste & $\mathrm{p}<0.02, \mathrm{df}=5$ & Rejected & $\mathrm{H} \rightarrow \mathrm{D}$ \\
\hline
\end{tabular}

\begin{tabular}{|l|l|l|l|l|}
\hline Stage & \multicolumn{1}{|c|}{ Product } & \multicolumn{1}{|c|}{$\mathrm{P}, \mathrm{df}$} & Hypothesis & $\mathrm{HI} \rightarrow \mathrm{LI}$ \\
\hline \hline \multicolumn{2}{|c|}{ Time Decision } & $\mathrm{p}<0.02, \mathrm{df}=5$ & Rejected & $\mathrm{S} \rightarrow \mathrm{GF}$ \\
\hline & Television & $\mathrm{p}<0.05, \mathrm{df}=5$ & Rejected & $\begin{array}{l}\mathrm{H} \rightarrow \\
\mathrm{GM}\end{array}$ \\
\hline \hline & Radio & $\mathrm{p}<0.02, \mathrm{df}=5$ & Rejected & $\mathrm{W} \rightarrow \mathrm{S}$ \\
\hline \hline & Edible Oil & $\mathrm{p}<0.02, \mathrm{df}=5$ & Rejected & $\mathrm{H} \rightarrow \mathrm{D}$ \\
\hline & Tooth Paste &
\end{tabular}

\begin{tabular}{|c|c|c|c|c|}
\hline Stage & Product & $\mathrm{P}, \mathrm{df}$ & Hypothesis & $\mathrm{HI} \rightarrow \mathrm{LI}$ \\
\hline \multicolumn{5}{|c|}{ Brand Decision } \\
\hline & Television & $\mathrm{p}<0.02, \mathrm{df}=5$ & Rejected & $\mathrm{H} \rightarrow \mathrm{GM}$ \\
\hline & Radio & $\mathrm{p}<0.05, \mathrm{df}=5$ & Rejected & $\mathrm{H} \rightarrow \mathrm{D}$ \\
\hline & Edible Oil & $\mathrm{p}<0.02, \mathrm{df}=5$ & Rejected & $\mathrm{GM} \rightarrow$ \\
\hline & Tooth Paste & $\mathrm{p}<0.02, \mathrm{df}=5$ & Rejected & $\mathrm{H} \rightarrow \mathrm{GF}$ \\
\hline
\end{tabular}




\begin{tabular}{|l|l|l|l|l|}
\hline Stage & \multicolumn{1}{|c|}{ Product } & P,df & Hypothesis & HI $\rightarrow$ LI \\
\hline Type Decision & $\mathrm{p}<0.02, \mathrm{df}=5$ & Rejected & $\mathrm{S} \rightarrow \mathrm{GF}$ \\
\hline & Television & $\mathrm{p}<0.05, \mathrm{df}=5$ & Rejected & $\mathrm{H} \rightarrow \mathrm{D}$ \\
\hline & Radio & $\mathrm{p}<0.01, \mathrm{df}=5$ & Rejected & $\mathrm{W} \rightarrow \mathrm{S}$ \\
\hline \multicolumn{7}{|c|}{ Edible Oil Product } & $\mathrm{P}, \mathrm{df}$ & Hypothesis & $\mathrm{HI} \rightarrow \mathrm{LI}$ \\
\hline Stage & Two Wheeler & $\mathrm{p}<0.05, \mathrm{df}=5$ & Rejected & $\mathrm{H} \rightarrow \mathrm{GM}$ \\
\hline
\end{tabular}

\begin{tabular}{|c|l|l|l|l|}
\hline Stage & \multicolumn{1}{|c|}{ Product } & \multicolumn{1}{|l|}{$\mathrm{P}, \mathrm{df}$} & Hypothesis & $\mathrm{HI} \rightarrow \mathrm{LI}$ \\
\hline \multicolumn{2}{|c|}{ Dealer Decision } & $\mathrm{p}<0.02, \mathrm{df}=5$ & Rejected & $\mathrm{H} \rightarrow \mathrm{D}$ \\
\hline & Television & $\mathrm{p}<0.05, \mathrm{df}=5$ & Rejected & $\mathrm{H} \rightarrow \mathrm{D}$ \\
\hline & Radio & $\mathrm{p}<0.02, \mathrm{df}=5$ & Rejected & $\mathrm{H} \rightarrow \mathrm{D}$ \\
\hline & Edible Oil & $\mathrm{p}<0.02, \mathrm{df}=5$ & Rejected & $\mathrm{H} \rightarrow \mathrm{D}$ \\
\hline & Tooth Paste &
\end{tabular}

$H I=$ Highest Involvement; $L I=$ Lowest Involvement

H=Husband, W=Wife, S=Son, D=Daughter, GF=Grandfather, GM=Grandmother

Detailed tables representing the Involvement of Family Members in the Purchase of Television, Radio, , toothpaste \& Washing powder are provided as follows; wherein the mean ranks represent the degree of involvement of the family members during the different decision stages as well as sub- decisions vis-à-vis their life stage

Table 2(a): Involvement of Family Members in the Purchase of Television

\begin{tabular}{|l|c|c|c|c|c|c|c|c|c|}
\hline \multicolumn{1}{|c|}{$\begin{array}{c}\text { Stages and Sub- } \\
\text { decisions }\end{array}$} & $\begin{array}{c}\text { Husband } \\
\mathbf{( 1 3 9 )}\end{array}$ & $\begin{array}{c}\text { Wife } \\
\mathbf{( 1 3 8 )}\end{array}$ & $\begin{array}{c}\text { Son } \\
\mathbf{( 8 6 )}\end{array}$ & $\begin{array}{c}\text { Daughter } \\
\mathbf{( 5 6 )}\end{array}$ & $\begin{array}{c}\text { Grand } \\
\text { father (24) }\end{array}$ & $\begin{array}{c}\text { Grand } \\
\text { mother } \\
\mathbf{( 2 3 )}\end{array}$ & $\begin{array}{c}\text { Kruskal- } \\
\text { Wallis H } \\
\text { statistics }\end{array}$ & df & Inter $^{\text {Y }}$ \\
\hline Idea initiation & 202.88 & 218.89 & 309.69 & 299.75 & 123.83 & 174.46 & 91.062 & 5 & $\mathrm{~S}$ \\
\hline $\begin{array}{l}\text { Information } \\
\text { collection }\end{array}$ & 336.46 & 159.62 & 273.64 & 151.3 & 221.25 & 117.33 & 192.276 & 5 & $\mathrm{~S}$ \\
\hline Final decision & 351.88 & 164.67 & 238.24 & 146.79 & 225.75 & 132.5 & 210.914 & 5 & $\mathrm{~S}$ \\
\hline Amount Decision & 364.30 & 190.09 & 168.53 & 136.03 & 260.33 & 168.72 & 231.877 & 5 & $\mathrm{~S}$ \\
\hline Time Decision & 230.50 & 233.43 & 287.57 & 254.71 & 108.38 & 126.28 & 60.699 & 5 & $\mathrm{~S}$ \\
\hline Brand Decision & 330.40 & 168.13 & 273.38 & 165.83 & 166.42 & 134.17 & 164.424 & 5 & $\mathrm{~S}$ \\
\hline Type Decision & 246.41 & 223.93 & 284.83 & 242.93 & 94.17 & 141.67 & 62.816 & 5 & $\mathrm{~S}$ \\
\hline Dealer Decision & 362.33 & 153.29 & 232.97 & 152.22 & 224.85 & 155.24 & 277.069 & 5 & $\mathrm{~S}$ \\
\hline
\end{tabular}


Table 2(b): Involvement of Family Members in the Purchase of Radio

\begin{tabular}{|l|c|c|c|c|c|c|c|c|c|}
\hline \multicolumn{1}{|c|}{$\begin{array}{c}\text { Stages and Sub- } \\
\text { Decisions }\end{array}$} & $\begin{array}{c}\text { Husband } \\
\mathbf{( 8 4 )}\end{array}$ & $\begin{array}{c}\text { Wife } \\
\mathbf{( 8 4 )}\end{array}$ & $\begin{array}{c}\text { Son } \\
\mathbf{( 5 0 )}\end{array}$ & $\begin{array}{c}\text { Daughter } \\
\mathbf{( 3 2 )}\end{array}$ & $\begin{array}{c}\text { Grandfather } \\
\mathbf{( 1 5 )}\end{array}$ & $\begin{array}{c}\text { Grand } \\
\text { mother (12) }\end{array}$ & $\begin{array}{c}\text { Kruskal- } \\
\text { Wallis H } \\
\text { statistics }\end{array}$ & df & Inter $^{\text {R }}$ \\
\hline Idea Initiation & 154.35 & 134.85 & 124.22 & 113.5 & 189.17 & 127.5 & 16.334 & 5 & $\mathrm{~S}$ \\
\hline $\begin{array}{l}\text { Information } \\
\text { Collection }\end{array}$ & 179.87 & 110.36 & 140.13 & 101.38 & 184.97 & 91.58 & 59.364 & 5 & $\mathrm{~S}$ \\
\hline Final Decision & 191.57 & 117.02 & 128.01 & 84.59 & 154.43 & 96.42 & 77.3 & 5 & $\mathrm{~S}$ \\
\hline Amount Decision & 196.32 & 116.64 & 101.8 & 86.63 & 186.6 & 129.42 & 95.923 & 5 & $\mathrm{~S}$ \\
\hline Time Decision & 158.67 & 130.48 & 131.29 & 121.69 & 163.23 & 108.92 & 12.804 & 5 & $\mathrm{~S}$ \\
\hline Brand Decision & 181.2 & 106.71 & 147.73 & 90.72 & 167.3 & 126.63 & 66.895 & 5 & $\mathrm{~S}$ \\
\hline Model Decision & 181.16 & 107.28 & 146.94 & 98.47 & 162.7 & 111.29 & 64.843 & 5 & $\mathrm{~S}$ \\
\hline Dealer Decision & 193.36 & 104.14 & 139.72 & 97 & 142.6 & 107 & 99.813 & 5 & $\mathrm{~S}$ \\
\hline
\end{tabular}

Table 2(c): Involvement of Family Members in the Purchase of Edible Oil

\begin{tabular}{|c|c|c|c|c|c|c|c|c|c|}
\hline \multicolumn{10}{|c|}{ EDIBLE OIL } \\
\hline $\begin{array}{l}\text { Stages and Sub- } \\
\text { Decisions }\end{array}$ & $\begin{array}{c}\text { Husband } \\
(151)\end{array}$ & $\begin{array}{l}\text { Wife } \\
(150)\end{array}$ & $\begin{array}{l}\text { Son } \\
(89)\end{array}$ & $\begin{array}{l}\text { Daughter } \\
\text { (60) }\end{array}$ & $\begin{array}{l}\text { Grand } \\
\text { Father } \\
(25)\end{array}$ & $\begin{array}{l}\text { Grand } \\
\text { Mother } \\
(23)\end{array}$ & $\begin{array}{l}\text { Kruskal- } \\
\text { Wallis H } \\
\text { statistics }\end{array}$ & df & Inter $^{\Re}$ \\
\hline Idea Initiation & 210.12 & 343.15 & 157.84 & 240.63 & 210.44 & 328.80 & 130.500 & 5 & $\mathrm{~S}$ \\
\hline Information Collection & 234.68 & 317.26 & 174.89 & 216.30 & 222.72 & 321.61 & 74.460 & 5 & $S$ \\
\hline Final Decision & 244.25 & 311.20 & 172.53 & 202.21 & 226.16 & 328.11 & 73.078 & 5 & $S$ \\
\hline Amount Decision & 283.84 & 294.99 & 157.80 & 170.32 & 240.64 & 312.67 & 90.334 & 5 & $\bar{S}$ \\
\hline Time Decision & 187.21 & 347.81 & 163.60 & 286.08 & 201.12 & 316.11 & 156.105 & 5 & $\bar{S}$ \\
\hline Brand Decision & 218.99 & 331.82 & 168.12 & 216.48 & 239.90 & 336.65 & 105.290 & 5 & $S$ \\
\hline Type Decision & 212.33 & 337.99 & 170.37 & 213.98 & 240.96 & 336.93 & 115.903 & 5 & $S$ \\
\hline Quantity Decision & 219.98 & 337.94 & 176.65 & 201.62 & 231.30 & 306.07 & 107.323 & 5 & $\bar{S}$ \\
\hline Dealer Decision & 300.82 & 234.17 & 246.33 & 166.20 & 280.28 & 211.63 & 49.490 & 5 & $\bar{S}$ \\
\hline
\end{tabular}

Table 2 (d): Involvement of Family Members in the Purchase of Tooth Paste

\begin{tabular}{|l|c|c|c|c|c|c|c|c|c|}
\hline \multicolumn{10}{|c|}{ TOOTHPASTE } \\
\hline $\begin{array}{l}\text { Stages and Sub- } \\
\text { Decisions }\end{array}$ & $\begin{array}{c}\text { Husban } \\
\mathbf{d}(\mathbf{1 5 1})\end{array}$ & $\begin{array}{c}\text { Wife } \\
\mathbf{( 1 4 9 )}\end{array}$ & $\begin{array}{c}\text { Son } \\
\mathbf{( 8 9})\end{array}$ & $\begin{array}{c}\text { Daughter } \\
\mathbf{( 6 1 )}\end{array}$ & $\begin{array}{c}\text { Grandfath } \\
\text { er (24) }\end{array}$ & $\begin{array}{c}\text { Grand } \\
\text { mother (22) }\end{array}$ & $\begin{array}{c}\text { Kruskal- } \\
\text { Wallis H } \\
\text { statistics }\end{array}$ & df & Inter $^{\text {PR }}$ \\
\hline Idea Initiation & 193.14 & 263.89 & 305.11 & 313.84 & 129.25 & 244.11 & 80.875 & 5 & $\mathrm{~S}$ \\
\hline $\begin{array}{l}\text { Information } \\
\text { Collection }\end{array}$ & 224.02 & 246.50 & 305.04 & 280.09 & 146.10 & 236.80 & 38.440 & 5 & $\mathrm{~S}$ \\
\hline Final Decision & 234.22 & 244.43 & 304.05 & 271.41 & 145.92 & 209.27 & 34.880 & 5 & $\mathrm{~S}$ \\
\hline Amount Decision & 303.69 & 280.19 & 174.19 & 162.33 & 205.04 & 251.86 & 90.595 & 5 & $\mathrm{~S}$ \\
\hline Time Decision & 175.64 & 317.37 & 246.69 & 312.54 & 134.06 & 244.95 & 114.996 & 5 & $\mathrm{~S}$ \\
\hline Brand Decision & 219.31 & 253.78 & 301.14 & 301.72 & 142.19 & 179.55 & 55.226 & 5 & $\mathrm{~S}$ \\
\hline Pack Decision & 238.07 & 259.13 & 273.02 & 278.70 & 124.81 & 210.89 & 30.198 & 5 & $\mathrm{~S}$ \\
\hline Dealer Decision & 293.67 & 200.06 & 320.78 & 200.61 & 218.69 & 152.95 & 83.814 & 5 & $\mathrm{~S}$ \\
\hline
\end{tabular}




\section{Conclusion}

The cultural and sociological ethos in the Indian rural set up are undergoing a gradual change with increased literacy, a shift from agriculture to non-agricultural activities, emergence of 'individualized joint families', and increased media exposure, which have triggered changes in the purchase process and consumption patterns of rural consumers.

One can observe a gradual shift from unilateral decision making to joint decision making process marked by increased participation of wife and children. But, the involvement of family members in purchase decision process depends to a great extent on the nature of the product, stages of the purchase decision process, and the sub-decisions related to purchase.

Male Family Members (MFM), particularly, husband and grandfather, play a dominant role as far as the resource allocation and vendor selection is concerned in almost all the product categories. Female Family Members (FFM), particularly, wife and grandmother, play a dominant role and are actively involved in the purchase decisions involving household items thereby indicating the prevalence of traditional sex role norms in the Indian rural set up. Children are increasingly playing an active role not only in the purchase decision of FMCGs but also in the purchase of higher end items like television, two-wheeler. And they display significant level of brand awareness. The involvement of rural youth is growing in stages as well as sub decisions concerning color, brand, type and model

One of the most interesting and noticeable development vis-à-vis the rural set up in India is the emergence of 'individualized joint families' where individuals branch off to form nuclear families (with separate cooking arrangements), live separately on a daily basis and make independent purchase decisions for FMCGs. But unlike their urban counterparts, they bond with the 'parent' family for social occasions and seek the advice of family elders in important decisions involving heavy investments as is seen in the present study where grandfather is seen playing a dominant role especially in case of resource allocation in the purchase of nearly all the durables under study. 


\section{Marketing Implications}

As earlier stated, rural markets offer huge untapped potential to the marketers and academicians alike and the buying behaviour demonstrated by the inhabitants of rural India differs significantly from their urban counterparts. But, surprisingly, not much research has been done in the area of rural buying behaviour more so in the area of family purchase behaviour and the marketers usually try to extend urban marketing programmes to these rural areas, which generally do not produce the desired results.

An in-depth knowledge of the rural psyche and buying patterns is one of the prerequisites for making a dent into the rural market. The insights thus gained may also facilitate practitioners to reengineer their offerings keeping in mind the peculiar needs and preferences of the rural consumers The present study in addition to having academic worth has practical implications. The results of this study may prove to be useful in designing marketing strategies and in this context a number of suggestions have been made to the marketers in the which may serve as vital inputs in developing promotion campaigns, selecting markets, market segmentation and product design and development.

\section{Future Directions for Research}

As the geographical extent of this study was limited to the villages of Uttar Pradesh, India, similar studies in other regions of the country would add both breadth and depth to our understanding of the family as a decision making unit considering the simple fact that the rural market is not only large, but also geographically scattered and exhibits linguistic, regional, economic and cultural diversities.

Children have emerged as a dominant player in the purchase process involved in the purchase of not only FMCGs but also big ticket items. Thus, more studies dealing specifically with the involvement of children belonging to different age groups are needed to ascertain as to which group plays a more dominant role across different product category especially in the Indian rural context. 
The sub-cultural factor of religion, and the related dimension of religious orientation, also has been found to be associated with family decision making (Guber, 1991). They assume even greater significance in the Indian rural settings where buyer is strongly bagged down to local social and cultural pressures (customs, habits, religion, and attitude) which have indomitable influences on the buying pattern (Kashyap, 2000; Mathur, N 2005). This aspect needs to be explored in the Indian rural context. Considering the fact that the rural respondents are sometimes semi-literate and illiterate, the researchers need to reorient their enquiry approaches to get amore insightful outcome for e.g. innovative research tools like images with varying expressions to ascertain preference and liking, colour association tests could be used (Krishnamurthy, 2000; Krishnamacharyulu \& Ramakrishnan, 2002). Alternative research approaches like observational studies, interactive interviewing and focus group interviews can also be adopted.

\section{References}

Acharya et al. Women's autonomy in household Decision Making: A demographic study in Nepal. Reproductive Health, 7-15. (2010)" http://www.reproductive-healt h- journal.com/content/7/1/15

Ali, A. et al. Examining the Children's Influence in Family Decision making in Delhi (India), International Journal of Scientific $\mathcal{E}$ Engineering Research,3,(2), February-2012 http://www.ijser.org

Aneja, R. H. (1996, May 25). Marketing and selling in India in the year 2000. Economic and Political Weekly, M-26-30.

Bargal, H. (2004).Agriculture based industries and rural market. Retrieved on 2 Feb, 2004, www.technopreneur.net/timeis/technology/ MaySciTech/AgriIndustry.html

Beckman, T. N. \& Davidson, W. R. (1962). Marketing (7th ed.), NY, USA: Ronald Press

Belch, G., Belch, M. A. \& Ceresino, G. (1985). Parental and teenage influences in family decision making. Journal of Business Research, 13, 163-76.

Bernardt, K. L. (1974). Husband-wife influence in the purchase decision process for houses. Unpublished Doctoral Dissertation, University of Michigan, USA

Bijapurkar, R. (2002). The new improved Indian consumer. Retrieved on 2 May, 2004. http://www.businessworldindia.com/Dec0803/ coverstory01.asp, Bonfield, 1978 
Brehl \& Callahan Research (1967).Family Decision making. Time Marketing Information Research Report, 14-28.

Burns, A. C. \& Devere. S. (1981). Four situations and their perceived effects on husband and wife purchase decision making. Advances in Consumer Research, 736-41.

Census, (2011). http://censusindia.gov.in/2011-prov-results/paper2/ data_files/ india/Rural_Urban_2011.pdf

Converse, P. D., Huegy, W. W \& Mitchell, R.V. (1958).Elements of Marketing (6th ed.), Englewoods Cliffs, N.J., USA: Prentice-Hall

Cunningham, I. C. M. \& Green, R. T. (1974). Purchasing roles in the US family: 1955 and 1973. Journal of Marketing, 38, 61-4.

Davis, H. L. \& Rigaux, B. P. (1974). Perception of marital roles in decision processes. Journal of Consumer Research, 1, 51-62.

Davis, H. L. (1970).Dimensions of marital roles in consumer decision making.Journal of Marketing Research, 7, 168-77.

Davis, H. L. (1971). Measurement of husband wife influence in consumer purchase decision.Journal of Marketing Research, 8, 305-12.

Davis, H. L. (1972).Determinants of Marital Roles in a Consumer Purchase Decisions. Working Paper 72-14, European Institute for Advanced Studies in Management, Brussels, April 1972.

Davis, H. L. (1976). Decision making within the household. Journal of Consumer Research, 2, 241-60..

Dey, N. B. \& Adhikari, K. (1998, May 1998). Rural marketing challenges \& opportunities. Yojana, 21-22

Dobhal, S. (1999, Feb. 22). NUFgen marketing or selling to the new urban family.Business Today, 66-81.

Ferber, R. \& Chao Lee, L. (1974).Husband-wife influence in family purchasing behavior. Journal of Consumer Research, 1, 43-50.

Guber, S. S. (1991). Children of the 1990's.Marketing Review, 46, 16-30.

Gupta, S. \& Chundawat, D.S. (2002).Family and social influences in buying decision making - A study of television, Decision, 29 (2) July-Dec, 2002, 45-65.

Halan, D. (2003, November).Rural marketing is a different ballgame. Indian Management, 60-64.

Herbst, P.G. (1952). The measurement of family relationships. Human Relations, 5, 3-35.

Kashyap, P. (2005a). Selling to the hinterland.Business World-Marketing Whitebook, 89-104.

Kashyap, P. (2005b, September 7). Where the streets have no name. Economic Times, p.2.

Kashyap, P. (2000, January 15). In first person.Advertising \& Marketing, 8183. 
Kaur \& Singh.(2006) “Children In Family Purchase Decision Making In India and The West': A Review" Academy of Marketing Science Review Volume 2006 (8) (2006) http://www.amsreview.org/ article/kaur08-2006.pdf

Khairoowala, Z. \& Siddique, S. (2001). Buying behaviour of rural consumers in haat market-A case study of some selected villages of western U.P. Indian Journal of Marketing, XXXI (11-12), 14-24.

Khan, M. N. (2000).Dimensions of family decision making in the purchase of consumer products.Unpublished Doctoral Dissertation, Aligarh Muslim University, Aligarh, India.

Krishnamoorthy, R. (2000, October).Indian rural market: Problems and prospects. Indian Management, 52-55.

Krishnamurthy, N. (2000, April 15).The new decision maker.Advertising $\mathcal{E}$ Marketing, 126.

Krishnamacharyulu, C. S. G \& Ramakrishnan, L. (2002).Rural Marketing Text and Cases. India: Pearson Education.

Lokhande, M. A. (2003).Rural marketing - A study of consumer behaviour trends.Indian Journal of Commerce, 56 (2) April-Sep, 129-135.

Lokhande, M. A. (2004).Rural marketing - A study of consumer behaviour. Indian Journal of Marketing, XXXIV (12), 14-17.

Manjunatha. (2004).Rural marketing- Prospects. Indian Journal of Marketing, XXXIV (6), 24-25.

Mathur, N. (1995). Rural marketing.Indian Journal of Marketing, XXIV (4), 3-8.

Mishra, A. \& Dubey, A.K. "Participation of Rural Women in Decision Making". Indian Research Journal of Extension Education. 9 (3), September, 2009:23-25

Nagaraja, B. (2004). Consumer behaviour in the rural areas: A microlevel study on buying behaviour of rural consumers in Kavali Mandal. Indian Journal of Marketing, XXXIV . (11), 30-36.

Nandagopal, R. \& Chinnaiyan, P. (2005).Awareness on consumer finance in rural market: An analysis. Indian Journal of Marketing, XXXV, 32-35.

Nandgopal.\& Chinnaiyan, P.(2003).Brand preference of soft drinks in rural Tamil Nadu. Indian Journal of Marketing, XXXIII (1), 14-17.

Pareek, V. (1999, August 15). Stop .look .go. Adverting E Marketing, 58

Park, Jong-Hee, Tansuhaj, P. S.\& Kolbe, R. H. (1991).The role of love, affection and intimacy in family decision research. Advances in Consumer Research, 18, 651-55.

Prema, A. (1998, July). Marketing in rural context. Kurukshetra, 27-29.

Sayulu, K. \& Reddy, V.V. R. (2002).Buying behaviour of rural consumer in A.P. - An empirical study. Khadigramudyog, May, 244-257. 
Sathyavathi, M. (1996). Rural marketing: Thrust and challenges. Khadigramodyog, July, 461-466.

Shivakumar, K. \& Arun,G. (2002, October ).Buying behaviour in the hinterland. Indian Management, 55-57.

Singh, R. and P. Kaur. "Do Rural and Urban Families Decide 'Differently' to Buy?" ICFAI Journal of Marketing Management (August2004 ): 1728

Singla, B. \& Kumar, S. (2011). "Spousal roles in family purchase Decision making process".Asian Journal of Research in Social Science $\mathcal{E}$ Humanities, Volume 1(2)):193-203

Trehan R, \& Singh, H. (2003).A comparitive study on urban and rural consumer behaviour.Indian Journal of Marketing, XXXIV (7), 7-11

Veni, P. \& Vishwanath, B. "Influence of children in family decisionmaking - an empirical study on selected durable and nondurable goods", IJMMR Volume 2, Issue 12 (December, 2011):136142

Woodside \& Motes \& Wilkes, E. W. (1975). Husband-wife influence in purchasedecisions - A confirmation and extension. Journal of Marketing Research, 12, 224-7.

Wolff, J. L. (1958). What Makes Women Buy: A Guide to Understanding and Influencing the New Woman of Today. New York, USA: McGrawHill.

Woodside, A. G. \& Motes, W. H. (1979). Husband and wife perceptions of marital roles in consumer decision processes for six products. American Marketing Association Proceedings, 12, 214-219. American Marketing Association, Chicago, IL, USAs. 